\title{
An analysis of Brazilian sugarcane bagasse ash behavior under thermal gasification
}

\author{
Catia Fredericci ${ }^{1 *}$, Gerhard Ett ${ }^{1}$, Guilherme FB Lenz e Silva ${ }^{2}$, João B Ferreira Neto ${ }^{1}$, Fernando JG Landgraf ', \\ Ricardo L Indelicato ${ }^{2}$ and Tiago R Ribeiro ${ }^{1}$
}

\begin{abstract}
Background: Ashes from sugarcane were analyzed by X-ray fluorescence, ash content, X-ray diffraction, scanning electron microscopy (SEM), and energy dispersive spectroscopy (EDS). FactSage 6.4 database software was used to estimate viscosity at high temperatures $\left(900-1550^{\circ} \mathrm{C}\right)$ of them.

Results: The results showed that although ashes from sugarcane bagasse contain silica, most of its $\mathrm{SiO}_{2}$ is from soil contamination. Higher and lower silica samples treated at $1350^{\circ} \mathrm{C}$ for 20 minutes showed that the fine portion of fraction of the ashes melted at this temperature.

Conclusions: The melting phase could act as sticking flux for the coarse silica particles on the gasifier bottom wall, which could compromise the gasification process.
\end{abstract}

Keywords: Biomass; Sugarcane; Bagasse; Ashes; Gasification

\section{Background}

The Institute for Technological Research (IPT) is interested in the development of the gasification process (Figure 1). Gasification produces synthetic gas or syngas $\left(\mathrm{H}_{2}+\mathrm{CO}_{2}+\right.$ $\left.\mathrm{N}_{2}+\mathrm{CO}_{2}+\mathrm{H}_{2} \mathrm{O}+\mathrm{C}_{\mathrm{n}} \mathrm{H}_{\mathrm{m}}\right)$ which can then be converted into energy, Fischer Tropsch biodiesel or monomers. It has higher energy efficiency when compared to other uses of bagasse and can produce important base chemicals [1]. Gasification is very flexible to raw materials, allowing for local development. The greatest challenge is to overcome the initial investment barrier, and lowering the current evaluation of US\$3/W to US $\$ 1.2 / \mathrm{W}$ that would make it commercially competitive [2]. A project involving the construction and operation of a gasification pilot plant, one of the questions raised is the melting temperature of the ashes from bagasse and/or straw used as a feedstock fuel.

Sugarcane bagasse, as biomass, will be used in this work, due to its availability and promising potential. Brazil is the largest producer of sugarcane, with production concentrated in its South-Central region. Currently, the bagasse is used in boilers in the mills to produce energy and heat with typical $45 \%$ carbon content (dry mass) [3]. Brazil's

\footnotetext{
* Correspondence: catiaf@ipt.br

'Institute for Technological Research of São Paulo State, 05508-901 São Paulo, SP, Brazil

Full list of author information is available at the end of the article
}

sugarcane industry association (UNICA) reported that the amount of crushed surgarcane in the South-Central region in 2013/14 was $596.936 \mathrm{Mt}$, about $12 \%$ up from the 532.758 Mt produced in 2012/13 [4] that generated approximately $118 \mathrm{Mt}$ of wet bagasse. Even considering its utilization as fuel for energy generation (typically in steam boilers) in the production mills, Perrone et al. [5] report that there is still a $12 \%$ surplus of biomass that will increase proportionally with the increase of ethanol production, requiring solutions and innovative ideas in order to generate new economic value and opportunities for the sugar and alcohol industry. Elements including $\mathrm{N}$, $\mathrm{P}, \mathrm{K}, \mathrm{S}, \mathrm{Ca}, \mathrm{Mg}, \mathrm{Fe}, \mathrm{Zn}, \mathrm{B}, \mathrm{Cu}, \mathrm{Mn}, \mathrm{Cl}$ and $\mathrm{Si}$ considered as macro-, micro- and functional nutrients are essentials for increasing and sustaining crop yields [6]. At high temperatures these elements in bagasse or straw are involved in reactions leading to ash formation [7].

The temperature inside the gasifier should be sufficient to melt the ash that will be deposited on the wall of the gasifier forming a liquid slag which should flow out from the bottom of the gasifier [8]. The typical temperature for highly efficient processes should be bellow than $1500^{\circ} \mathrm{C}$. Entrained flow gasification works with liquid (bio-oil) or sub-millimeter solid particles (bagasse or straw particles). Entrained flow consists of a vertically placed cylindrical reactor at the top of which fuel (bio-oil or biomass) and a 


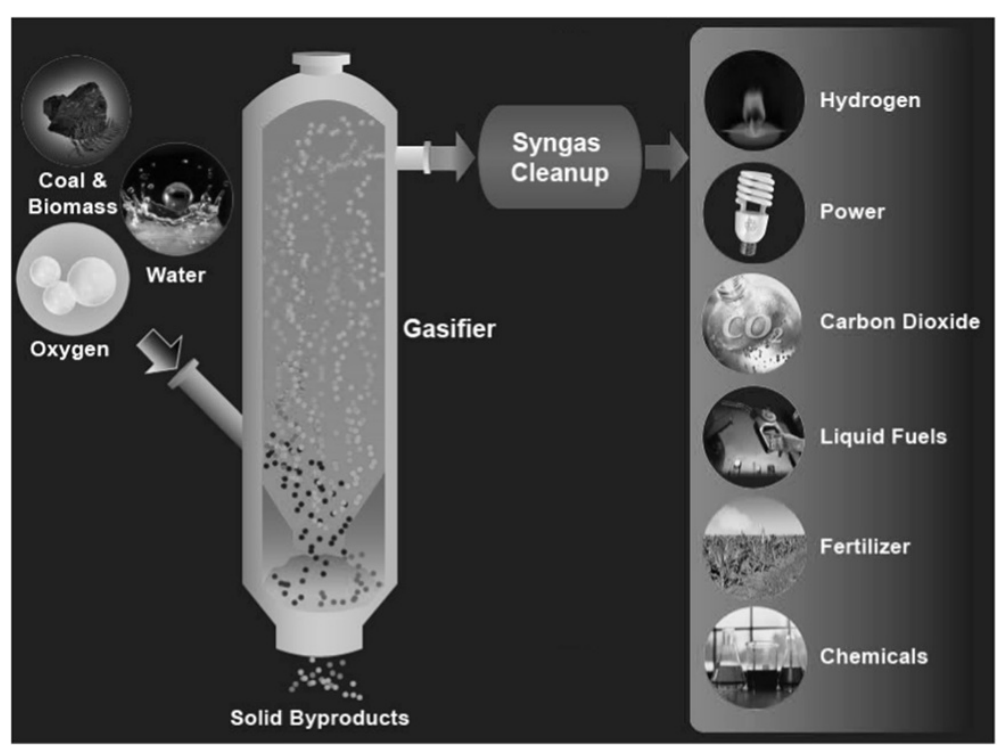

Figure 1 Gasification process (fuels, raw-materials, by-products, gasifier agents, and syngas applications), adapted from DOE/USA Department of Energy.

gasifying agent (air or $\mathrm{O}_{2}$ ) are inserted through a nozzle, usually in a swirling flow, forming a flame that carries either particles or droplets through the reactor as they undergo incomplete combustion, i.e. gasification. Residence times are small, temperature and pressure can as be high as $1500^{\circ} \mathrm{C}$ and 40 bar, respectively, ensuring low tar production [9].

The aim of this work is to analyze the ash from sugarcane bagasse generated from sugarcane mills in some regions of the São Paulo State - Brazil. The results obtained in this research will provide inputs for determining the preferred processing conditions for the gasifier.

\section{Methods and Experimental}

Bagasse from four different sugarcane mills in São Paulo State - Brazil were collected from the stock area of the mills, in the period of December 2011 to December 2012 and were used for the study (Table 1). Currently, the bagasse presents $\sim 50 \%$ moisture content. They were dried at $80^{\circ} \mathrm{C}$ for $48 \mathrm{~h}$ for obtaining bagasse on a dry weight basis

Table 1 Samples of bagasse and sugarcane and their sources

\begin{tabular}{ll}
\hline Bagasse samples collected in the mill & Location of the Mill \\
\hline $\mathrm{BA}$ & Araraquara $-\mathrm{SP}\left(^{*}\right)$ \\
$\mathrm{BI}$ & Iracemapólis $-\mathrm{SP}$ \\
$\mathrm{BRP}$ & Rio das Pedras $-\mathrm{SP}$ \\
$\mathrm{BS}$ & Sorocaba $-\mathrm{SP}$ \\
Sugarcane sample collected in the field & Location of the Mill \\
BAL & Araraquara $-\mathrm{SP}$ \\
\hline
\end{tabular}

(*)SP - São Paulo State - South-east Brazil. (about 2\% humidity). Initial scanning electron microscopy (FEI-Quanta 3D FEG-SEM) was used to evaluate the shape and morphology. A small assortment of each bagasse sample was deposited on carbon tape secured on brass stubs and then coated with a thin layer of gold. The qualitative analysis of the chemical elements was performed using an energy dispersive spectrometer (EDAX System). The secondary electron images were taken using a voltage of 5 to $15 \mathrm{kV}$.

Twenty grams of bagasse were heat treated at $600^{\circ} \mathrm{C}$ for $30 \mathrm{~min}$ to generate ashes. Each experiment was repeated 10 times for each bagasse under the same conditions and the percentage of generated ashes was given as the average of them.

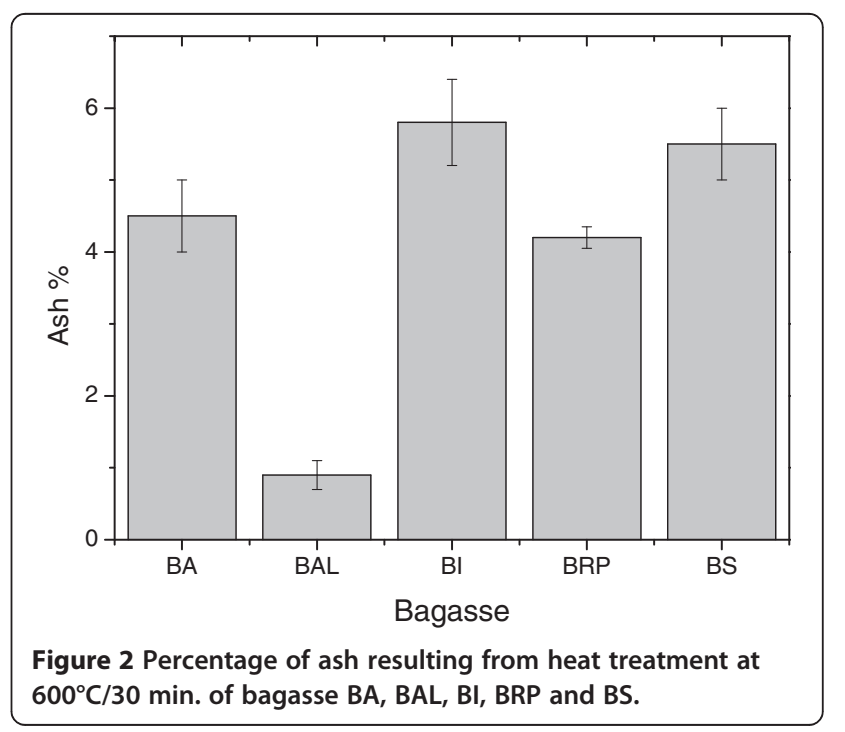


Table 2 Chemical analysis of the ashes obtained by X-ray fluorescence from BA, BI, BRP, BS and BAL samples (wt\%)

\begin{tabular}{llllll}
\hline Oxide & $\mathbf{B A}$ & $\mathbf{B I}$ & $\mathbf{B R P}$ & $\mathbf{B S}$ & $\mathbf{B A L}$ \\
\hline $\mathrm{SiO}_{2}$ & 73.4 & 56.1 & 80.5 & 65.3 & 11.1 \\
$\mathrm{Al}_{2} \mathrm{O}_{3}$ & 7.7 & 18.0 & 5.6 & 10.6 & 0.3 \\
$\mathrm{P}_{2} \mathrm{O}_{5}$ & 5.1 & 2.0 & 4.7 & 5.5 & 6.9 \\
$\mathrm{~K}_{2} \mathrm{O}$ & 3.1 & 4.9 & 3.1 & 3.0 & 27.0 \\
$\mathrm{MgO}$ & 1.7 & 1.8 & 1.8 & 1.7 & 19.0 \\
$\mathrm{Fe}_{2} \mathrm{O}_{3}$ & 5.1 & 7.8 & 1.5 & 8.5 & 0.3 \\
$\mathrm{CaO}$ & 1.6 & 5.0 & 1.4 & 1.9 & 8.9 \\
$\mathrm{SO}_{3}$ & 0.5 & 2.0 & 0.5 & 0.7 & 21.0 \\
$\mathrm{TiO}_{2}$ & 1.3 & 1.8 & 0.4 & 2.5 & 0.1 \\
$\mathrm{Cl}$ & $<0.1$ & $<0.1$ & $<0.1$ & $<0.1$ & 5.0 \\
\hline
\end{tabular}

$\mathrm{Na}_{2} \mathrm{O}<0.1, \mathrm{ZnO}<0.02, \mathrm{CuO}<0.02, \mathrm{MnO}<0.2$.

The samples collected from different mills were named with the following identification: BA, BI, BRP and BS. Ash samples from Araraquara region that were entirely processed in the IPT's laboratory were named BAL and they were used for comparative purposes. In this case, the BAL sample stalks were milled in the laboratory and were dried at $80^{\circ} \mathrm{C}$ for $48 \mathrm{~h}$ for obtaining bagasse on a dry weight basis (about $2 \%$ humidity). Finally, they were heat treated at $600^{\circ} \mathrm{C}$ for $30 \mathrm{~min}$. Table 1 shows the ash sample identifications and their mill.

Ashes were analyzed by X-ray diffraction (Shimadzu XRD 6000 , using Co $K_{\alpha}$ radiation), X-ray fluorescence pressed powder pellet technique (Philips, model PW 2404), scanning electron microscopy (FEI-Quanta 3D FEG-SEM) coupled to an energy dispersive spectrometer (EDAX System), and sieving analysis for particle size distribution. The computer thermodynamic package FactSage 6.4, in the modulus Glass database, was used to calculate the viscosity of the ash as a function of temperature from $900^{\circ} \mathrm{C}$ to $1550^{\circ} \mathrm{C}$.

About $0.2 \mathrm{~g}$ of ash was compacted in a stainless steel mold with a $0.5 \mathrm{~cm}$ diameter. The resulting cylindrical samples were put in an alumina boat crucible with $5 \mathrm{~cm}$ in length and were heat treated at $1350^{\circ} \mathrm{C}$ for $20 \mathrm{~min}$ in order to analyze the fusibility behavior of the ashes. The surfaces of the heat treated samples were analyzed by scanning electron microscopy using a JEOL-SEM model JSM 6300, coupled to an energy dispersive spectrometer Noran System.

\section{Results and discussion}

\section{Ash from bagasse}

The temperature of $600^{\circ} \mathrm{C}$ was chosen to burn out all carbon and to prevent as much as possible the loss of potassium [10]. Figure 2 shows the results of ash percentage from the bagasse samples (BA, BAL, BI, BRP and BS) on a dry weight basis. It can be observed that the amount of ash is in the range of 4 to $6 \mathrm{wt} \%$ and is agreement with some data reported in the literature [11,12], although one publication indicates a percentage of ash as high as $20 \mathrm{wt} \%$ [13]. An interesting fact was that the amount of ash resulted from the heat treatment of BAL is smaller than that obtained from the heat treated bagasse from the sugar mills, including BA bagasse. The reasons for this discrepancy will be discussed later.

\section{Ash composition and crystalline phases}

Table 2 shows the chemical composition of the ashes obtained by X-ray fluorescence (XRF). The ashes from

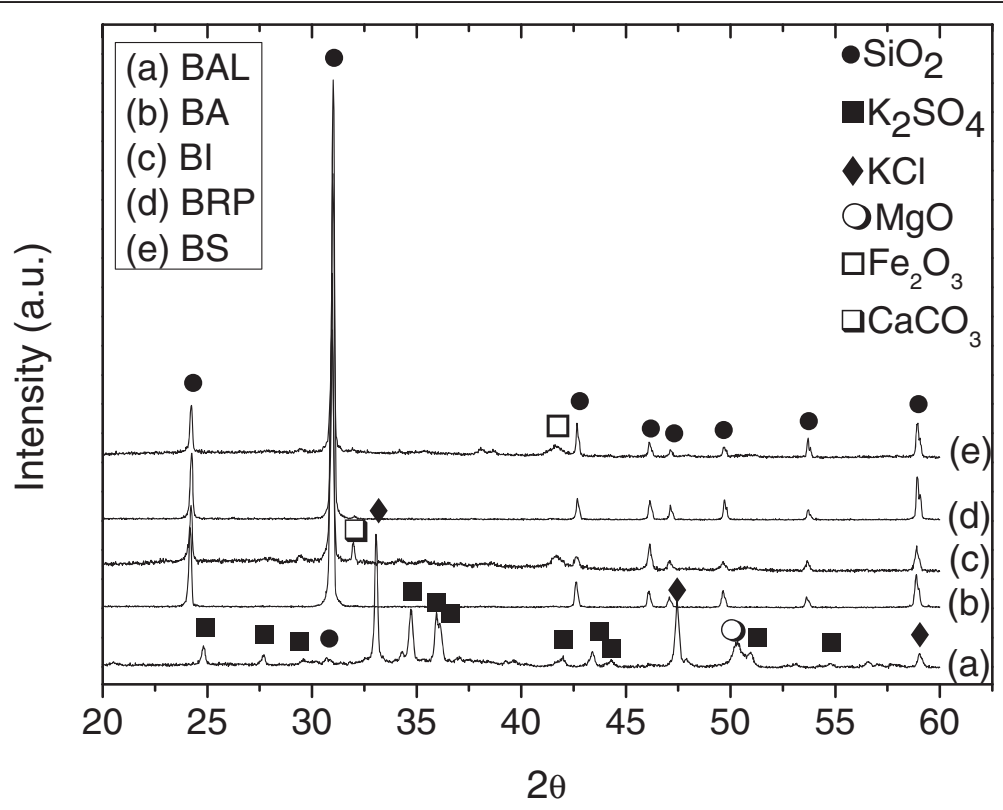

Figure $3 \mathrm{XRD}$ patterns of the ashes resulted from the heat treatment at $600^{\circ} \mathrm{C} / 30 \mathrm{~min}$ of $\mathrm{BA}, \mathrm{BAL}, \mathrm{BI}, \mathrm{BRP}$ and $\mathrm{BS}$ samples. 


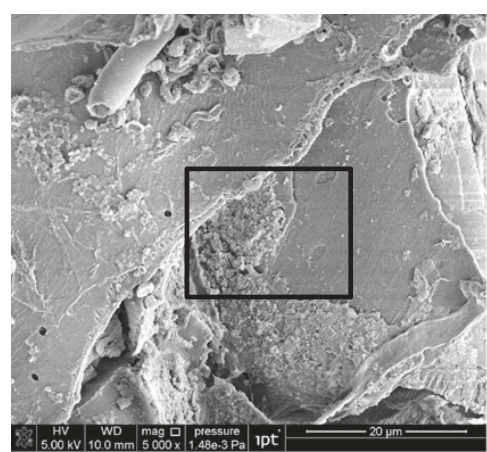

(a)

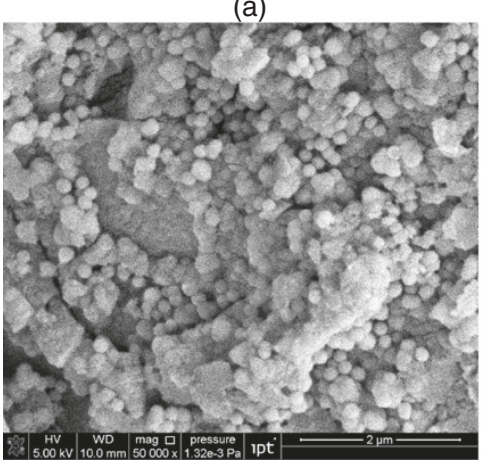

(c)

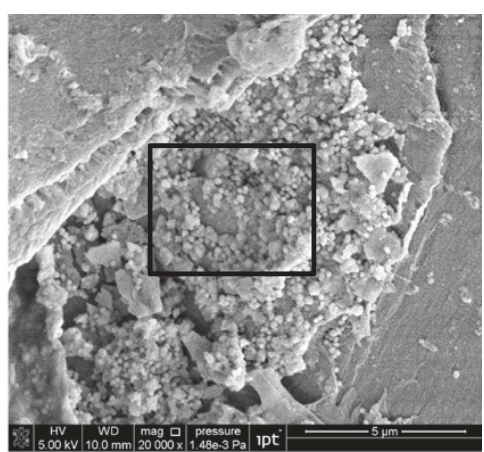

(b)

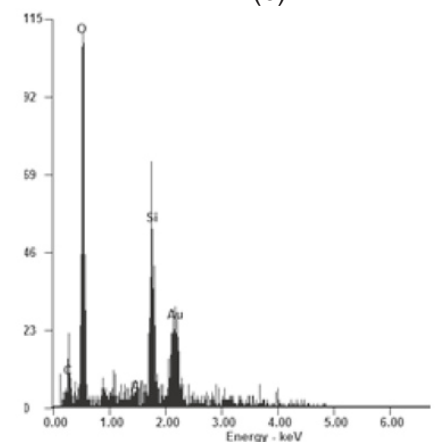

(d)

Figure 4 SEM micrographs (SE image) of bagasse BA: (a), (b) and (c). The squares represents the magnified area; (d) EDS microanalysis from area (c).

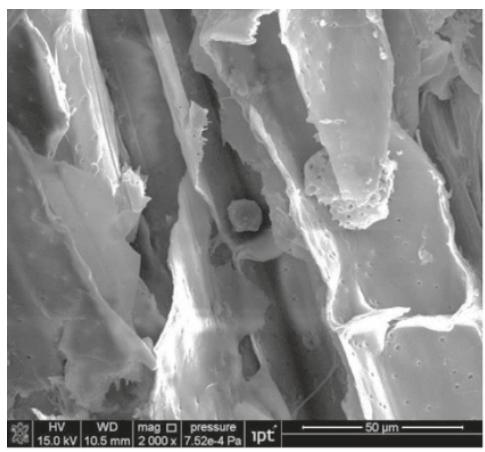

(a)

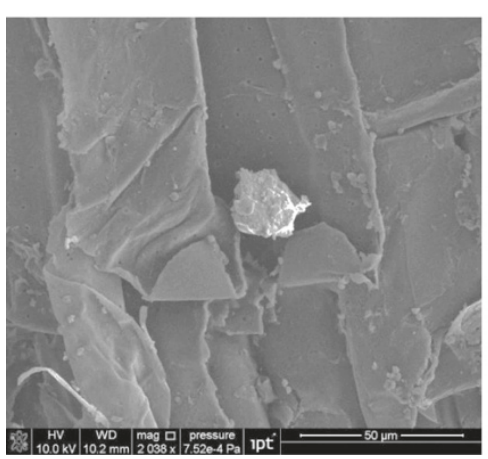

(c)

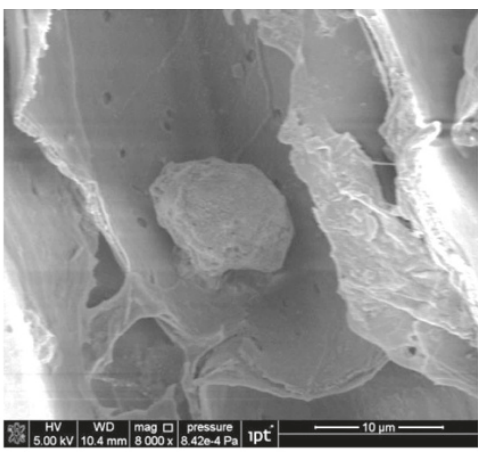

(b)

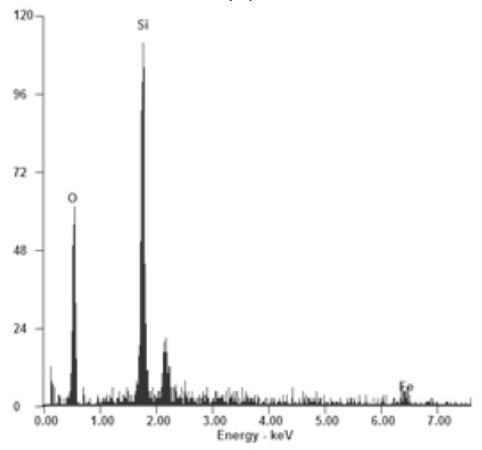

(d)

Figure 5 (a) SEM of bagasse BA, (b) magnified area from (a), (c) SEM of bagasse BA in different region of (a) and (d) EDS of the particle presented in (b). 
Table 3 Granulometric size distribution by sieving for the ashes obtained through the heat treatment of $\mathrm{BA}, \mathrm{BI}$, BRP, BS and BAL samples

\begin{tabular}{llllll}
\hline Sieves mesh & BA & BI & BRP & BS & BAL \\
\hline+50 & 3.3 & 10.3 & 6.6 & 2.3 & - \\
$-50+100$ & 22.9 & 13.4 & 20.1 & 15.2 & - \\
$-100+170$ & 2.1 & 18.1 & 4.4 & 3.3 & - \\
$-170+270$ & 41.7 & 13.7 & 39.2 & 35.8 & - \\
$-270+325$ & 7.2 & 3.5 & 4.7 & 3.5 & - \\
-325 & 21.7 & 40.2 & 24.2 & 39.7 & 100.0 \\
\hline
\end{tabular}

bagasse collected in the sugar/ethanol mills present high amounts of $\mathrm{SiO}_{2}$, as high as $56 \mathrm{wt} \%$, and low amounts of alkaline oxide, $\mathrm{P}_{2} \mathrm{O}_{5}$ and $\mathrm{Al}_{2} \mathrm{O}_{3}$. On the other hand, the BAL bagasse presents low amounts of silica ( 11 wt\%) and $\mathrm{Al}_{2} \mathrm{O}_{3}$, and high amount of alkaline and earth alkaline oxides $\left(\mathrm{K}_{2} \mathrm{O}, \mathrm{MgO}\right.$ and $\left.\mathrm{CaO}\right)$. The contents of macro and micronutrients for plant growth $\mathrm{Fe}_{2} \mathrm{O}_{3}, \mathrm{ZnO}$, $\mathrm{CuO}, \mathrm{Cl}$ (chloride) and $\mathrm{MnO}$ was also determinate. Boron and Nitrogen were not determined by X-ray fluorescence since they are considered light elements.

As can be seen in Figure 3 the XRD patterns show a significant difference between the ashes from bagasse processed in the mill and in the laboratory. The ashes from bagasse $\mathrm{BA}, \mathrm{BRP}, \mathrm{BI}$ and $\mathrm{BS}$ present $\mathrm{SiO}_{2}$ in the form of quartz as the mainly crystalline phase, while the primary phase for the ash from BAL is potassium chloride, followed by potassium sulfate and silica appears as a minor crystalline phase, consistent with the chemical composition showed in Table 2. It is known that silicon is considered a beneficial element to plants and is absorbed through the roots as silicic acid. Malavolta [14] reported that stalks are richer in $\mathrm{K}(109 \mathrm{~kg} / \mathrm{ha})$ than in $\mathrm{Si}(98 \mathrm{~kg} / \mathrm{ha})$, which is only in agreement with BAL bagasse.

Figure 4 shows SEM micrographs of BA bagasse and exhibits spherical nanometer scale, $\mathrm{SiO}_{2}$ rich particles that can be attributed to absorbed silicon from the soil by sugarcane. Sugarcane harvesting in Brazil is done in two ways: by machine and by manual process after sugarcane burning (São Paulo State law does not allow sugarcane burning from June to November due to increased air pollution). In both cases there is soil contamination of the sugarcane, especially in times of rain, as in the Brazilian summer, when bagasse samples for this study were collected. Although in some sugar and alcohol mill plants occurs the washing process of the sugarcanes, it seems not very effective in removing all their soil impurities. When the shredded sugarcane passes through several mills in the plant production of sugar and alcohol, soil particles become trapped in the fibers of the sugarcane.

The micrograph shown in Figure 5, obtained by scanning electron microscopy, shows a particle rich in $\mathrm{Si}$ and $\mathrm{O}$, confirming the presence of soil contamination in bagasse after the milling process. Thus the $\mathrm{SiO}_{2}$ present in the ash composition of the BA, BI, BRP and BS bagasse is a combination of silicon oxide from soil contamination and from absorbed silicon from the soil in the sugarcane. This is one of the reasons for the discrepant results of ash amount obtained from bagasse collected in plant mills [11-13].

\section{Ash particle size distribution}

Table 3 presents the particle size distribution of the ashes. Except for BAL ash, the others present particles with sizes greater than $40 \mu \mathrm{m}$ (\# 325 mesh) and significant amounts of particles in the 53 to $88 \mu \mathrm{m}(+270-$ 170 mesh) size range. It can be seen in Figure 6 that particles of BA ash in the 53 to $88 \mu \mathrm{m}$ range exhibit the typical rounded morphology of quartz sand grains from soil (Figure 6b) [15].

\section{Ash fusibility}

Patterson and Hurst [16] proposed that a silica ratio of $100 \mathrm{SiO}_{2} /\left(\mathrm{SiO}_{2}+\mathrm{Fe}_{2} \mathrm{O}_{3}+\mathrm{CaO}+\mathrm{MgO}\right)<80$ is required for entrained flow gasifiers, if the $\mathrm{SiO}_{2}$ amount is high, a flux is required for decreasing the ash viscosity, and to minimize the flux amount a $\mathrm{SiO}_{2} / \mathrm{Al}_{2} \mathrm{O}_{3}$ ratio of 1.6-2.0 is optimal. Table 4 presents the relations proposed by

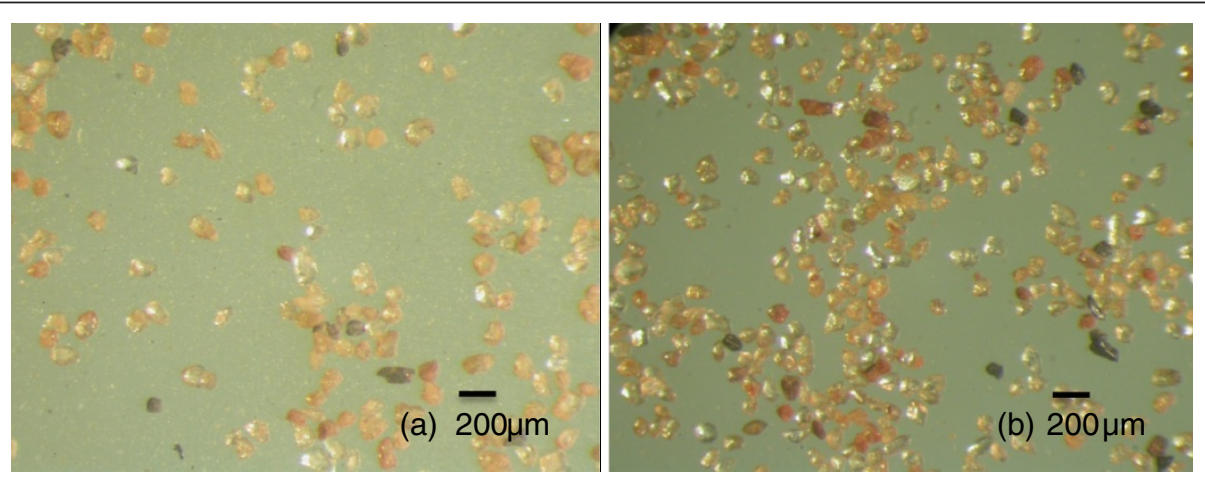

Figure 6 Reflected light microscopy of the $-170+270$ mesh $(-88+53 \mu \mathrm{m})$ fraction in ash (a) BA and (b) soil from Araraquara area. 
Table 4 Ash properties used to determine viscosities in the entrained flow gasifiers (Patterson and Hurst)

\begin{tabular}{lll}
\hline Ashes & $\mathbf{S i O}_{\mathbf{2}} /\left(\mathbf{S i O}_{\mathbf{2}}+\mathrm{Fe}_{\mathbf{2}} \mathbf{O}_{\mathbf{3}}+\mathrm{CaO}+\mathbf{M g O}\right)(\%)$ & $\mathbf{S i O}_{\mathbf{2}} / \mathbf{A l}_{\mathbf{2}} \mathbf{O}_{\mathbf{3}}$ \\
\hline BAL & 28.2 & 37.0 \\
BI & 79.3 & 3.1 \\
BS & 84.4 & 6.2 \\
BA & 89.7 & 9.5 \\
BRP & 94.5 & 14.4 \\
\hline
\end{tabular}

Patterson and Hurst for the ash from BAL, BI, BS, BA and BRP. As can be seen, only ash from BI and BAL has an index lower than 80. However, regarding the $\mathrm{SiO}_{2} /$ $\mathrm{Al}_{2} \mathrm{O}_{3}$ relation all ashes present indices higher than 2.0. According to Peterson and Hurst [16], all bagasse from the stock area of mills (BA, BRP, BI and BS) should be mixed with flux to produce an ash with optimal viscosity for an entrained flow gasifier. It is known that viscosity can only be used as an indication of slag in the gasifier, and that the melting characteristic of ash is generally lower in reducing atmosphere [16-18]. Iron is the principal fluxing element that controls ash melting under reducing conditions [17]. We have used the $\mathrm{Fe}_{2} \mathrm{O}_{3}$ and its equivalent $\mathrm{FeO}$ values presented in Table 2 to calculate ash viscosities using the FactSage 6.4 a database computing systems in chemical thermodynamics. The results could be a guide to evaluate bagasse quality for gasification. For software calculations, chloride and $\mathrm{SO}_{3}$ were not considered, since they are not available on FactSage database software. Although $\mathrm{P}_{2} \mathrm{O}_{5}$ is also not available, it was added to $\mathrm{SiO}_{2}$, since it is a glass former.

Figure 7 presents the curve of calculated viscosity for the ash from BRP, BA, BS, BI and BAL. Higmann and Burgt [18] reported that to ensure continuous flow, a slag viscosity less than $25 \mathrm{~Pa}$.s is necessary at temperatures lower than $1400^{\circ} \mathrm{C}$. As can be seen in Figure 7 the calculated viscosities of the ash from BRP, BA, BS and BI at $1350^{\circ} \mathrm{C}$ are $2.7 \times 10^{4}$ Pa.s, $8.7 \times 10^{3}$ Pa.s, $1.6 \times 10^{3}$ Pa.s, and $0,5 \times 10^{3}$ Pa.s, which are very high. The viscosity of ash BAL is lower than 25 Pa.s (log $\eta \sim 1.4$ Pa.s) at $900^{\circ} \mathrm{C}$. Figure 8 shows the ash samples heat treated at $1350^{\circ} \mathrm{C}$, and it is possible to observe the difference on viscosity from it. Wang and Massoudi [8] reported that one possibility to obtain viscosity lower than 25 Pa.s is to increase the gasifier operating temperature, that however can lead to a reduction of the overall efficiency of the process. Even for temperatures as high as $1550^{\circ} \mathrm{C}$, for the samples from the stock area of mills, only the ash from BI presented a viscosity near 25 Pa.s ( $\log \eta \sim 1.4$ Pa.s). Great differences in viscosity were not observed when using $\mathrm{FeO}$ instead of $\mathrm{F}_{2} \mathrm{O}_{3}$ on the chemical composition of the ashes.

Figure 9 shows that to obtain a viscosity close to 25 Pa.s, an addition of $35 \mathrm{wt} \%$ and $15 \mathrm{wt} \%$ of $\mathrm{CaO}$, as flux, should be added to the BRP and BI, respectively [19]. There are some difficulties with the utilization of flux when the biomass is bagasse due the difficulty in homogenizing it with the flux. Furthermore, it is reported that with flux addition

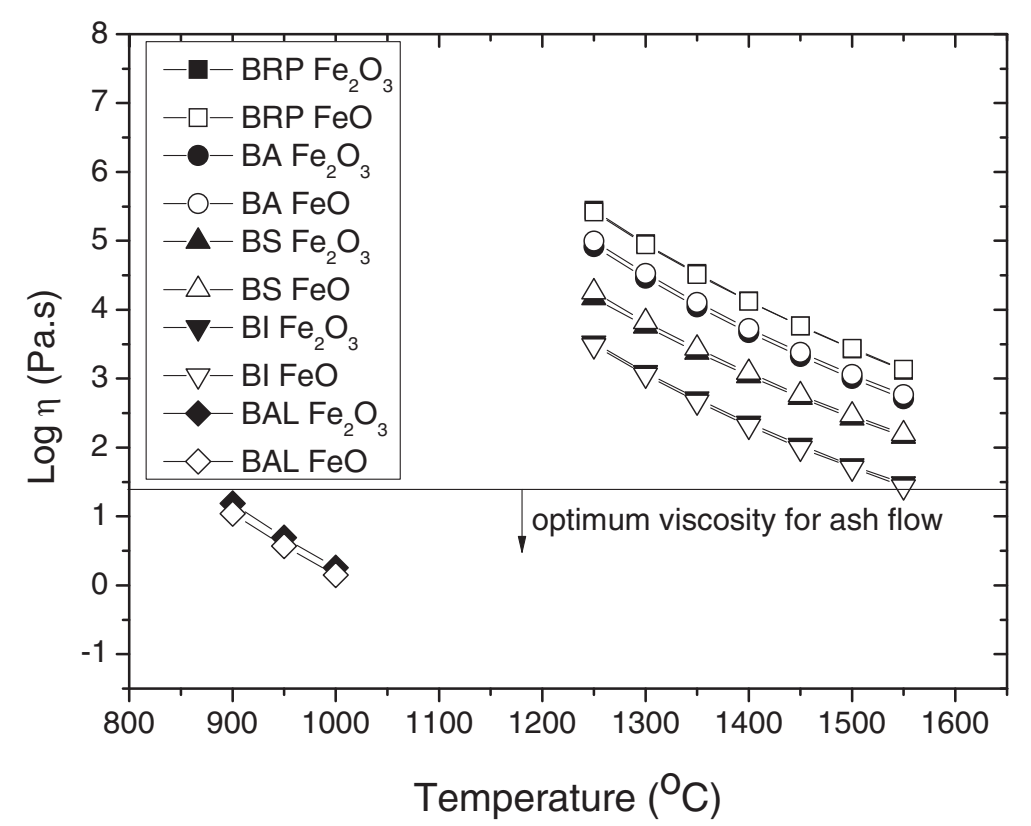

Figure 7 Ash viscosity as a function of temperature for the ashes from BRP, BA, BS BI and BAL, calculated by FactSage using the data from Table 2. 


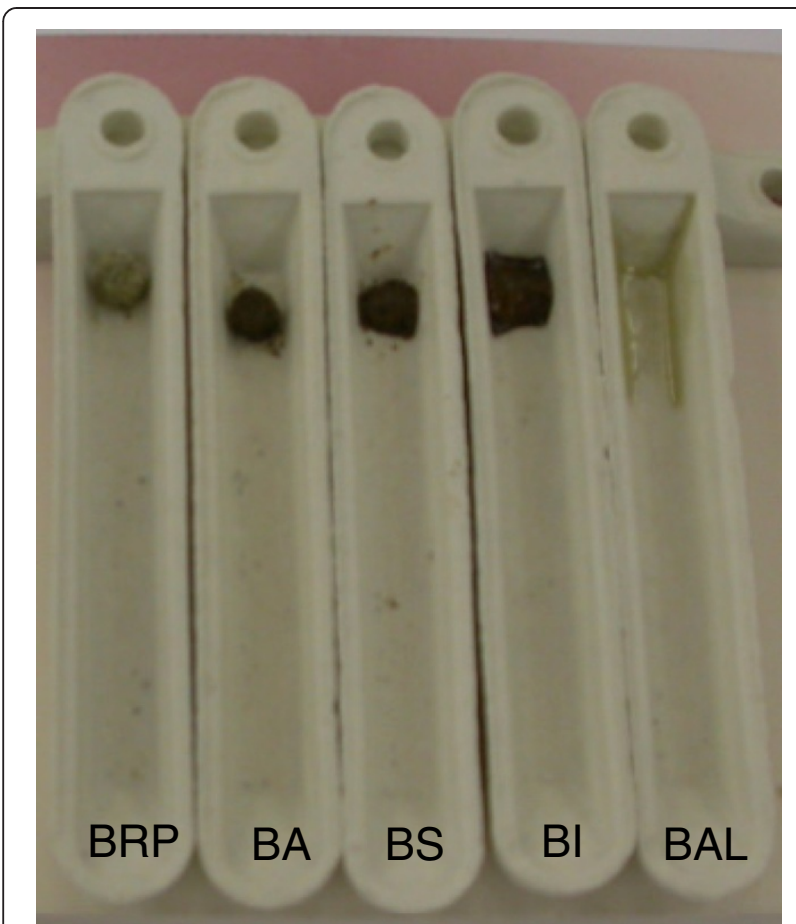

Figure 8 Samples of ashes BRP, BA, BS, BI and BAL heat treated at $1350^{\circ} \mathrm{C} / 20 \mathrm{~min}$.

all the ash must be melted and more heat is required for greater ash content, thereby reducing gasifier efficiency [15].

In Figure 10 and Figure 11 are shown the surfaces of the $\mathrm{BRP}$ and $\mathrm{BI}$ ash samples, heat treated at $1350^{\circ} \mathrm{C} / 20 \mathrm{~min}$ in an oxidizing atmosphere (air). The ashes from BRP and BI represent high and the low amounts of silica (quartz), respectively, of the bagasse from the stock area of mills. It can be seen that particles of $\mathrm{SiO}_{2}$ are surrounded by a glass phase resulting from the reaction of the components of the fine fraction of the ash, consisting of the plant nutrients $\left(\mathrm{SiO}_{2}, \mathrm{Al}_{2} \mathrm{O}_{3}, \mathrm{~K}_{2} \mathrm{O}, \mathrm{CaO}, \mathrm{MgO}, \mathrm{P}_{2} \mathrm{O}_{5}\right.$, and $\mathrm{Fe}_{2} \mathrm{O}_{3}$, for example).

If bagasse BA, BI, BRP and BS would be used for gasification, as received, coarse particles of $\mathrm{SiO}_{2}$ could became stuck and tightened on the inner and bottom walls of the gasifier, which could be dangerous for the process since the agglomeration of quartz particles on the bottom wall could cause a blockage of the gasifier. This could lead to severe unscheduled shutdowns and high operation maintenance costs [20]. It is necessary to find technological and economically feasible alternatives for removing silica from bagasse before its gasification processing.

\section{Conclusions}

The ashes from sugarcane bagasse processed in the sugarcane mills from São Paulo State present quartz as the main crystalline phase from soil contamination. On the other hand, the ash from bagasse cleaned and processed in laboratory has potassium chloride and potassium sulfate as principal the crystalline phases, and $\mathrm{SiO}_{2}$ as a minor phase. Analysis from scanning electron microscopy of the surface of ash samples from mill bagasse heat treated at $1350^{\circ} \mathrm{C}$ for 20 minutes showed that the fine fraction of the ashes melt at this temperature and act as flux for coarse quartz sintering. This can cause

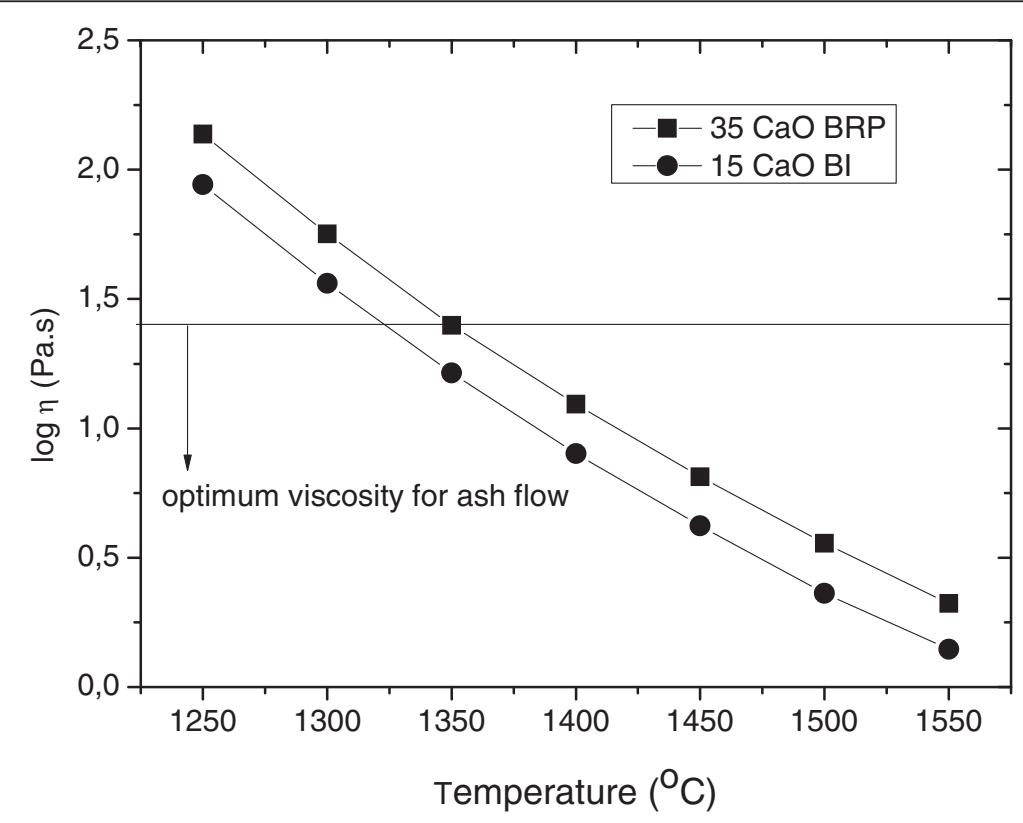

Figure 9 Ash viscosity as a function of temperature for the ash from BRP and BI, calculated by FactSage, using the data from Table 2, with addition of $35 \mathrm{wt} \% \mathrm{CaO}$ in $\mathrm{BRP}$ and $15 \mathrm{wt} \% \mathrm{CaO}$ in $\mathrm{BI}$. 

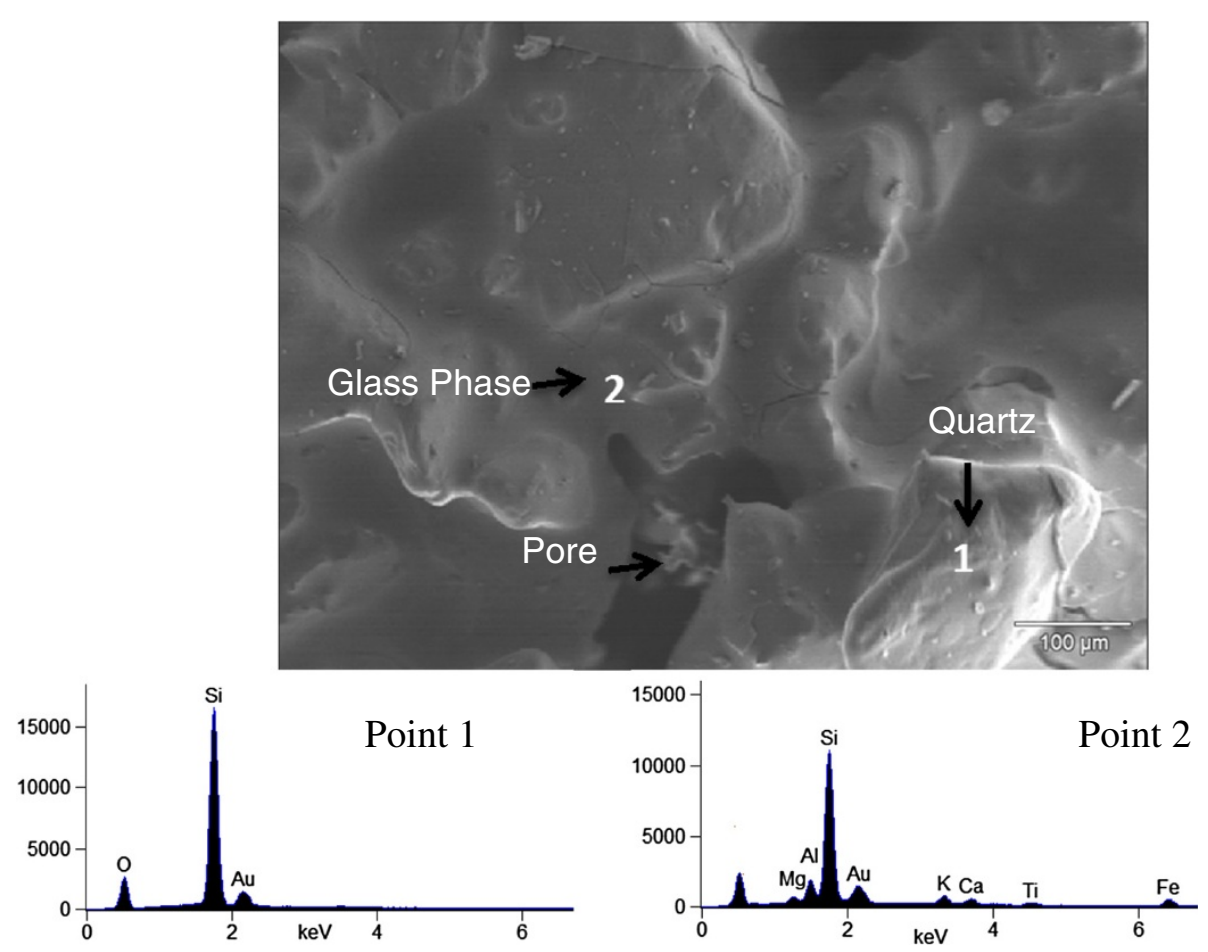

Figure 10 Surface of the BRP ash sample, heat treated at $1350^{\circ} \mathrm{C} / 20 \mathrm{~min}$.

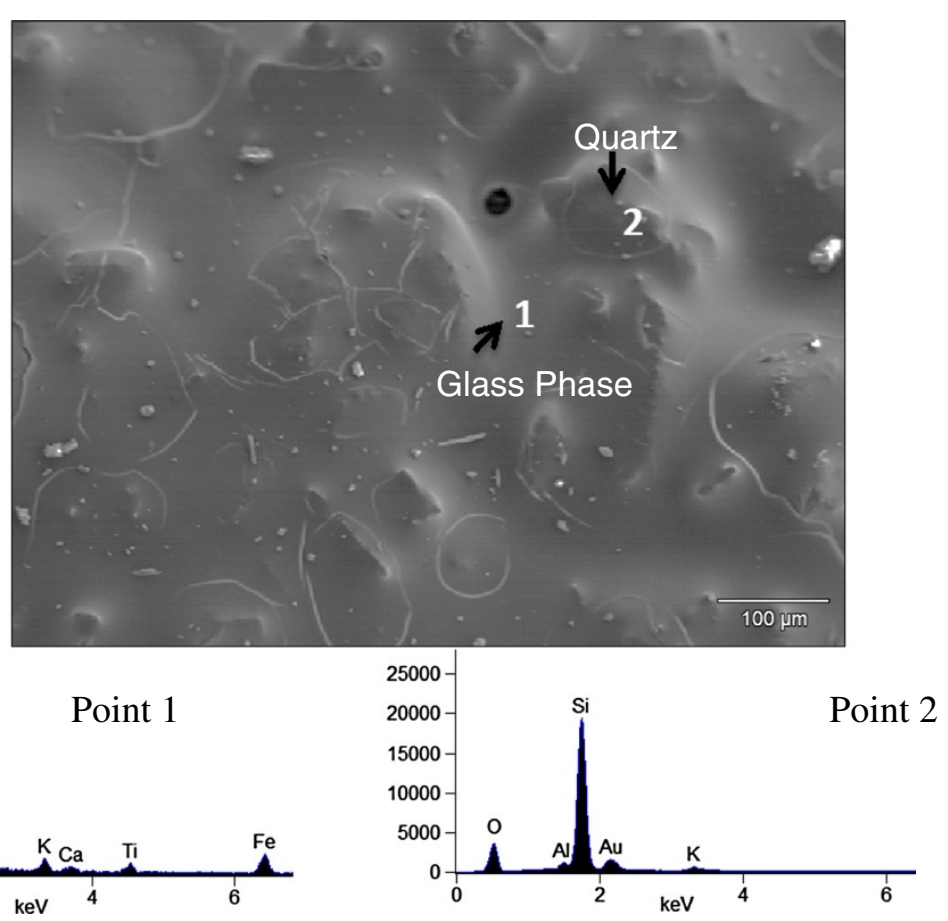

Figure 11 Surface of the $\mathrm{BI}$ ash sample, heat treated at $1350^{\circ} \mathrm{C} / 20 \mathrm{~min}$. 
aggregation of $\mathrm{SiO}_{2}$ on the bottom wall of the gasifier that can compromise the process when using sugarcane bagasse as biomass for gasification. It is very important to study possibilities for removing soil contamination before bagasse processing.

\section{Competing interests}

The authors declare that they have no competing interests.

\section{Authors' contributions}

All authors have contributed substantially to the work. They read and approved the final manuscript.

\section{Acknowledgements}

The authors kindly thank the Sugarcane Mills from São Paulo State - Brazil for donating the sugarcane bagasse, Ruben Spitz from Brown University, Claudia Maria G. de Souza and Miguel Papai Jr. of the The Center for Chemistry and Manufactured Goods - CQuim - for the X-ray fluorescence analyses.

\section{Author details}

'Institute for Technological Research of São Paulo State, 05508-901 São Paulo, SP, Brazil. ${ }^{2}$ Polytechnic School, University of São Paulo, 05508-010 São, SP, Brazil.

Received: 1 April 2014 Accepted: 25 August 2014

Published online: 14 October 2014

\section{References}

1. U.S. DOE - National Energy Technology Laboratory (NETL) Advantages and efficiency of gasification. available at: http://www.netl.doe.gov/research/coal/ energy-systems/gasification/gasifipedia/clean-power. Accessed 22 Jul 2014

2. Yu ASO, Landgraf FJG, Ett G, Silveira JRF (2013) IPT Bagasse Gasification Conceptual Engineering. In: International Society of Sugar Cane Technologists, 28, 2013, Proceedings. Stab and Coopersucar, São Paulo, pp 1-15

3. Paes LAD, Marian FR Carbon Storage in Sugarcane Fields of Brazilian SouthCentral Region, CTC Technical report 2011., available at: http://sugarcane.org/ resource-library/studies/Carbon\%20storage\%20in\%20sugarcane\%20fields\%20of \%20Brazilian\%20South-Central\%20region.pdf. Accessed 22 Jul 2014

4. (2013) UNICA - União da Indústria de Cana-de-Açúcar (Sugarcane Industry Union) - UNICA Data Press Release., p 30, available at: http://www.unicadata.com.br/listagem.php?idMn=86. Accessed 22 Jul 2014

5. Perrone CC, Appel LG, Maia Lellis GL, Ferreira FM, de Sousa AM, FerreiraLeitão VS (2010) Ethanol: an evaluation of its scientific and technological development and network of players during the period of 1995 to 2009 Waste Biomass Valor 2(1):17-32

6. Savant NK, Korndörfer GH, Datnoff LE, Snyder GH (1999) Silicon nutrition and sugarcane production: a review. J Plant Nutr 22(12):1853-1903

7. Jenkins BM, Baxter LL, Miles TR Jr, Miles TR (1998) Combustion Properties of Biomass. Fuel Process Tech 54:17-46

8. Wang P, Massoudi M (2011) Effect of Coal Properties and Operation Conditions on Flow Behavior of Coal Slag in Entrained Flow Gasifiers: A Brief Review. In: U.S. Department of Energy (DOE) National Energy Technology Laboratory (NETL)., pp 1-29, Report number: DOE/NETL-2011/1508

9. U.S. DOE National Energy Technology Laboratory (NETL)., available at: http://www.netl.doe.gov/File\%20Library/Research/Coal/energy\%20systems/ gasification/gasifipedia/index.html. Accessed 29 Jul 2014

10. Liao $Y$, Yang G, Ma X (2012) Experimental study on the combustion characteristic and alkali transformation behavior of straw. Energy Fuels 26:910-916

11. Ohman M, Pommer L, Nordin A (2005) Bed agglomeration characteristics and mechanisms during gasification and combustion of biomass fuels. Energy Fuels 19(4):1742-1748

12. Batra VS, Urbonaite S, Svensson G (2008) Characterization of unburned carbon in Bagasse Fly Ash. Fuel 87:13-14, 2972-2976

13. Rezende CA, de Lima MA, Maziero P, de Azevedo ER, Garcia W, Polikarpov (2011) Chemical and morphological characterization of sugarcane bagasse submitted to a delignification process for enhanced enzymatic digestibility. Biotech Biofuels 4(54):1-18
14. Malavolta E (1994) Fertilizing for high yield sugarcane - international potash institute Basel/Switzerland. Bull Am Meteorol Soc 14:1-102, http:// ebookbrowsee.net/ipi-bulletin-14-fertilizing-for-high-yield-sugarcane-pdfd230056405

15. Merrison JP (2012) Sand transport, erosion and granular electrification. Aeolian Res 4:1-16

16. Patterson JH, Hurst HJ (2000) Ash and slag qualities of australian bituminous coals for use in Slagging Gasifiers. Fuel 79(13):1671-1678

17. Huffman GP, Huggins FE, Dunmyre GR (1981) Investigation of the hightemperature behavior of coal ash in reducing and oxidizing atmosphere. Fuel 60(7):585-597

18. Higman C, van der Burgt M (2008) Gasification, 2nd edn. Elsevier, New York

19. Guo Z-Q, Han B-Q, Dong H (1997) Effect of coal slag on the wear rate and microstructure of the $\mathrm{ZrO}_{2}$-bearing chromia refractories. Ceramics Int 23(6):489-496

20. Brooker D (1993) Chemistry of deposit formation in a coal gasification syngas cooler. Fuel 72(5):665-670

doi:10.1186/s40538-014-0015-z

Cite this article as: Fredericci et al:: An analysis of Brazilian sugarcane bagasse ash behavior under thermal gasification. Chemical and Biological Technologies in Agriculture 2014 1:15.

\section{Submit your manuscript to a SpringerOpen ${ }^{\odot}$ journal and benefit from:}

- Convenient online submission

- Rigorous peer review

- Immediate publication on acceptance

- Open access: articles freely available online

- High visibility within the field

- Retaining the copyright to your article

Submit your next manuscript at $>$ springeropen.com 